\title{
Excellent short-term CD4 recovery with a PI- and NRTI-sparing regimen in triple-class failure HIV-infected patients: raltegravir, maraviroc, etravirine
}

\author{
S Nozza*, F Visco, A Soria, L Galli, S Salpietro, N Gianotti, E Carini, \\ A Bigoloni, G Fusetti, G Tambussi, A Lazzarin and A Castagna
}

Address: San Raffaele Scientific Institute, Milan, Italy

* Corresponding author

from Ninth International Congress on Drug Therapy in HIV Infection

Glasgow, UK. 9-13 November 2008

Published: 10 November 2008

Journal of the International AIDS Society 2008, I I (SuppI I):P45 doi:I0.I I86/I758-2652-II-SI-P45

This abstract is available from: http://www.jiasociety.org/content/II/SI/P45

(C) 2008 Nozza et al; licensee BioMed Central Ltd.

\section{Purpose of the study}

With the availability of new drug classes, the full suppression is a realistic goal even for heavily pre-treated patients. We prospectively evaluated the magnitude of CD4 recovery (CR) in this setting.

\section{Methods}

We decided to simultaneously screen triple class failing patients (pts) followed at San Raffaele Hospital in three Expanded Access Programs: raltegravir (MK0518-023), maraviroc (A4001050), etravirine (TMC125-C214). Salvage therapy was prescribed according to: viral tropism, screening genotype and previous resistance tests. Data were collected at baseline (BL) and at 4, 12, 24, 36 and 48 weeks. Generalized linear regression model was applied. Results are reported as median (Q1-Q3).

\section{Summary of results}

Up to date, 68 pts reached week 24 (W24) without modification of the initial regimen; age 44.5 (41.7-49.9) years, 17 (25\%) women, 10 (17.2\%) IVDU, infected since 15.0 (12.5-18.4) years, ARV exposure of 13.0 (11.6-15.4) years, CDC C stage 32 (47\%). At BL: CD4 195 (87-306) cells $/ / \mu \mathrm{L} ; \mathrm{CD} 4 \% 11.8$ (7.0-17.5), HIV-RNA 4.2 (3.8-5.0) $\log 10$ copies/mL and CD4 nadir 73 (22-178) cells/ $\mu \mathrm{L}$. No difference in BL characteristics were found according to the group regimen prescribed. (Table 1.)
At week 24, 14 (93\%), 13 (76\%), 14 (74\%), 15 (94\%) had HIV-RNA $<50$ copies/mL in group A, B, C, D, respectively $(\mathrm{p}=0.238)$.

At multivariable analysis, a significantly different CR was related to therapy group $(p=0.035)$ and positively related to BL HIV-RNA $(\mathrm{p}=0.049)$. CR was higher in group A (adjusted mean: $214.8 \pm 37.3)$ than group B (129.2 \pm $33.5, \mathrm{p}=0.062)$ or group $\mathrm{C}(115.7 \pm 30.5, \mathrm{p}=0.023)$ or group $\mathrm{D}(91.7 \pm 33.3, \mathrm{p}=0.005)$. No independent effect of age $(\mathrm{p}=0.834)$, gender $(\mathrm{p}=0.392)$, HIV risk factor $(\mathrm{p}$ $=0.522), \mathrm{CD} 4 \%(\mathrm{p}=0.297)$ and CD4 nadir $(\mathrm{p}=0.195)$ was observed. Despite the high pill number, RAL +MVC+ETR were very well tolerated; serious adverse events were diagnosed in two pts: spondylodiscitis (one), anal cancer (one).

\section{Conclusion}

Salvage therapy with RAL+ MVC+ETR showed an excellent short-term CD4 recovery. Reasons for this success could include: presence of active drugs blocking consecutive targets of viral replication, high doses of MVC required with this regimen, avoidance of ritonavir and NRTI toxicity. 
Table I:

\begin{tabular}{lcccc}
\hline & N & BL HIV-RNA & BL CD4 & W24 CD4 \\
\hline Group A: RAL+MVC+ETR & 15 & $4.2(3.9-5.1)$ & $276(90-528)$ & $552(398-718)$ \\
Group B: RAL + MVC or ETR + PI sparing OBT** & 17 & $4.0(3.9-4.7)$ & $197(94-295)$ & $378(330-447)$ \\
Group C: RAL + MVC or ETR +PI/r* based OBT** & 20 & $4.7(3.8-5.3)$ & $160(63-198)$ & $306(239-361)$ \\
Group D: RAL + PI/r* based OBT** & 16 & $4.2(3.6-4.9)$ & $240(121-329)$ & $349(276-504)$ \\
\hline
\end{tabular}

$*_{\text {in }} 33 / 36$ darunavir/r $* *$ OBT = optimized background therapy.

Publish with Bio Med Central and every scientist can read your work free of charge

"BioMed Central will be the most significant development for disseminating the results of biomedical research in our lifetime." Sir Paul Nurse, Cancer Research UK

Your research papers will be:

- available free of charge to the entire biomedical community

- peer reviewed and published immediately upon acceptance

- cited in PubMed and archived on PubMed Central

- yours - you keep the copyright 